\title{
Dr Pralad Yonzon (1951-2011): In memoriam
}

\author{
Pitamber Sharma
}

On 31 October 2011 Dr Pralad Yonzon was returning home from his office at Resources Himalaya in Sanepa; as he pedaled along the Ring Road near Balkhu, his bicycle was rammed by a heavy truck, and he was killed almost instantly. With the tragic demise of Dr Pralad Yonzon, Nepal has lost a top class scientist, a true patriot and a wonderful human being. The Himalayan region has lost a dedicated conservationist who believed that it is the continued practice of "good" science based on rigorous evidence that can secure the Himalayan environment for future generations. Pralad was by far one of the finest field biologists in this part of the world.

I first met Pralad about 38 years ago at the TU campus in Kirtipur. I had just started my teaching career at the Department of Geography and Pralad was doing his Masters in zoology. He was doing some research and wanted advice on mapping. Even at that time I was struck by his single-mindedness and his seriousness in research. After completing his Masters with a gold medal Pralad began his career as a field biologist with the Smithsonian Institute's Nepal Tiger Ecology Project. He was with the project for nearly four years. Later he taught at Tri-Chandra College, and was also associated with the Natural History Museum. This experience led him to found Resources Nepal, an independent research and training institute in 1986. In 2004 Resources Nepal was transformed into Resources Himalaya Foundation (RHF), a non-profit organization dedicated to environmental research and mentorship of a new generation of scientists. Linking new knowledge in conservation biology and social sciences to triangulate issues related to environmental conservation and livelihoods is the stock-in-trade of Resources Himalaya. In 2005 impressed by Pralad's vision and pragmatism, I agreed to join the Governing Board of Resources Himalaya.

Under Pralad's dynamic and innovative leadership Resources Himalaya has completed nearly 200 small and large research projects in Nepal, Sikkim and Bhutan. Studies on the status of Nepal's Red Panda, the ACAP management plan, the first ever Rhino count in Nepal, the Nepal Biodiversity Action Plan, the Snow Leopard and Elephant Conservation Action
Plans, a ten volume study on the ecology and conservation plans for the Churia ranges, a GIS data base for Nepal's Conservation areas, studies and Management Plans for the conservation areas and national parks of Bhutan, biodiversity studies in Sikkim - Resources Himalaya has produced major milestones in the field of Himalayan conservation. Pralad's doctoral work on the habitat and status of the Red Panda in Nepal, based on an intensive two-year program of field work, is a landmark for its academic rigor and innovative use of GIS. His work in Bhutan, which spanned nearly a decade, was remarkable not only for the discovery of the Bengal Tiger at altitudes above $3000 \mathrm{~m}$, but also for the framework that he helped create for the management of newly created conservation areas and national parks. He also worked for some time in Vietnam and Indonesia, sharing his vast experience in the field of conservation biology.

In 1989 Pralad earned a $\mathrm{PhD}$ in wildlife biology from the University of Maine in the United States. Pralad chose to devote all his time in research, teaching and mentoring the new generation of conservationists. Creating science based new knowledge and using it for environmental conservation was his predominant motivation. Personal gain never figured in his approach to conservation; in fact, he often subsidized the activities of Resources Himalaya through his remunerations. For his work on conservation he was awarded the Order of the Golden Arc by the Government of the Netherlands in 2002. His alma mater, the University of Maine, honored him with the Distinguished Alumnus Award in 2007 and the Professional Excellence Award in 2008. He was the President of the Asia Section of the International Society of Conservation Biology for 2002-2006, a rare honour for a Nepali scientist. Resources Himalaya was awarded the prestigious MacArthur Award in 2007, largely for work that Pralad carried out through the institution. Pralad used the award money to build the Conservation Chautari, which today houses the Resources Himalaya Foundation.

Pralad's experience with Nepal's officialdom, the University and a variety of non-governmental organizations in the field of conservation taught him a simple but 
unpalatable truth: that conservation was being used as a bait for attracting resources, while the real backbone of sustainable conservation - mentoring a competent, dedicated and conscientious younger generation - was being neglected. Through Resources Himalaya Pralad almost single-handedly guided the programme to mentor a generation of conservationists imbued with a scientific temperament, and dedicated to the cause of environmental conservation. He guided the Environmental Graduates in Himalaya (EGH), a network of environmental graduates that stands as a sister organization of the RHF in training and mentoring the younger scientists. Today, well over 200 graduates have been mentored by Pralad, and nearly 20 are pursuing their doctoral studies in various Universities of the world. EGH members edit and publish a weekly environmental e-newsletter, Headlines Himalaya, which informs readers of new developments in environmental conservation in the Himalayan countries. It has nearly 3000 readers in over 70 countries around the world. Habitat Himalaya, another flagship publication of the RHF, reports on contemporary conservation research, primarily by young scientists.
Mentoring was Pralad's passion. As a teacher and researcher he was a role model for his students. He kept abreast of contemporary knowledge in conservation and wildlife biology and passed on the latest developments in the field to his students. He had the courage and the integrity to ask questions that were uncomfortable to many but were prompted by "good" science and by his vast experience in the field. In the field of environmental and wildlife conservation Pralad truly was a "conscience keeper", the rarest of breeds among Nepali conservation biologists.

Pralad was the resource par excellence of the Resources Himalaya Foundation. With his passing he leaves behind an institution and the legacy of dedicated hard work and mentoring of the younger generation of conservationists. We at Resources Himalaya are devoted to the cause that Pralad championed, and firmly believe that the life and work of Dr. Pralad Yonzon will inspire others to carry on the work of protecting our environment for all time.

Pitamber Sharma is the Chair of the Governing Board of the Resources Himalaya Foundation. He can be reached at ps@resourceshimalaya.org.

\title{
Pralad Yonzon, colleague, friend, conservationist, student of Red Panda
}

\author{
Malcolm L Hunter
}

Pralad Yonzon is widely recognized as one of the leading conservation biologists in Asia, particularly as a mentor to students throughout the Himalayan region, but my relationship with him goes back to a period, in the 1980s, when he was still a student himself. I first met Pralad in 1984 when he was working on a Master's degree at Colorado State University, supported by a Fulbright scholarship, an honor that recognized several years of research on tigers in Chitwan National Park and on Himalayan pheasants. As his MS work was drawing to a close he started to explore opportunities for continuing for a $\mathrm{PhD}$, and he wrote to me because I had done some work in the Indian Himalayas. He wrote with a compelling idea for a project on the red panda. Pralad knew that the red panda had received almost no attention from field researchers and might be in jeopardy because of habitat degradation. It was also a charismatic creature, arguably more adorable than the better known giant panda. More importantly, he saw that the red panda had the potential to become a flagship or umbrella species for high-altitude forests throughout the Himalayas, perhaps filling the role of snow leopards in the alpine zone, and tigers and rhinos in the lowlands. I recognized that this was an unusually worthwhile idea for which we should be able to find sponsorship, and on that basis I convinced my colleagues to offer Pralad a teaching assistantship that would allow him to come to the University of Maine for a year to do his initial course work and pursue funding for his research.

We came to know each other quite well right from the beginning because Pralad, his wife Binu, and daughter Patanjali stayed with me in my small log cabin for a couple of weeks after arriving in Maine. A few months later Pralad and I made a trip to Washington, DC, to seek funding. Traveling on a shoestring budget, we ended up sharing a bed one night at the apartment of some friends who worked for the World Wildlife Fund. Thankfully he was not a snorer! The funding expedition was successful and a year later I was able to visit Pralad in Nepal, joining him for one of his first reconnaissance trips to Langtang National Park. It always made me smile when he introduced me to local people as his "guru," for while in Nepali the word simply means "teacher," in English the word connotes some kind of exotic spiritual guide. Wherever we were, it was always a pleasure to spend time with Pralad. He was a wonderful story teller with quite a repertory of tales from his adventures in the field; often they were misadventures, but he did not mind laughing at himself.

Imagine trying to conduct research from a tent in a Himalayan winter with heavy snows threatening to bury you, your crew, and equipment. To make a long story short, Pralad managed to undertake the first thorough field study of red pandas. From this work he published two important papers in leading journals, one that focused on the field biology of 


\title{
Dr Pralad Yonzon: Guru of field methodology
}

\author{
Dinesh Raj Bhuju
}

Conservation biologist Pralad Yonzon had an unsual ability to devise and adapt new methodologies aptly suitable for field work in the steep and rugged mountain terrain of the Himalaya. He was, notably, an early adopter of GPS and GIS technologies in Nepal. He made the technologies popular in scientific studies.

One area where Yonzon made great contributions was his seminal study of the elusive red panda (Ailurus fulgens). In revealing the ecology of this keystone species, Yonzon undertook groundbreaking research on the understudied Langtang Himal. This was his first ecological research as an independent researcher, and it earned him a $\mathrm{PhD}$ from the University of Maine (USA) in 1989 and shaped his professional career as a wildlife biologist. Long before that, however, he had already earned a reputation for careful observation as a field biologist for the Nepal Tiger Ecology project of the Smithsonian Institute, a position he assumed soon after graduating from Tribhuvan University in 1974.

In 1973 Nepal had established its first protected area, Chitwan National Park to provide sanctuary for a critical ecosystem and charismatic species including the Greater Onehorned Rhinoceros (Rhinoceros unicornis), whose population had dwindled to below 100 due to poaching and habitat encroachment. Scientists and planners in Nepal and around the world were eager to know if the national park was contributing to the recovery of the rhinoceros. A population study of rhinos dispersed in the flood-plain and foothills of a national park with an area of $932 \mathrm{~km}^{2}$ was a formidable task. By 1990 there had been at least nine attempts to estimate the population of the rhino (Martin and Vigne 1996); some of these relied on estimation (e.g., Spillett and Tamang 1966, Laurie 1978), helicopter census (Caughley 1969, Pelinck and Upreti 1972), or census by photo (Dinerstein and Price 1991). Yonzon, typically, applied an innovative approach. He devised a swiping technique, using domestic elephants in block transect counts. The team deployed a dozen elephants moving about $100 \mathrm{~m}$ from each other. Two or more researchers on each elephant were tasked to focus on the area either $100 \mathrm{~m}$ to the left or $100 \mathrm{~m}$ to the right, shouting as soon as they spotted a rhino. This was in 1994, when we did not have cell-phones or other effective communications devices.

Count Rhino 94 was Nepal's first full length rhino population study and represented a collaborative effort on the part of Nepal's major governmental and non-governmental organizations, including the Department of National Parks and Wildlife Conservation, the King Mahendra Trust for Nature Conservation, the World Wildlife Fund, and Resources Nepal (Yonzon 1994). The census reported that there were between 446 and 466 rhinos in Chitwan. With this finding, researchers confirmed that the rhino population had indeed made a healthy recovery from the lowpoint in the late 1960s. Since then, the government has periodically conducted several annual rhino surveys, following the protocol developed by Pralad Yonzon.

In 1999 Resources Himalaya undertook to compile an ecological database for Chure, a zone consisting of tertiary unconsolidated and highly erodible fluviatile sediments in the southtern foothills of the Himalaya, a region also known as the Siwaliks. It was the first such study at a landscape level covering an entire geographic zone from east to west of the country. For several years, Nepal has been confronting a problem with marauding the wild elephants. In 2007 Yonzon designed an action research on elephant conservation for the Western Terai Landscape Complex Project (WTCLP). The objective was to determine the distribution and status of captive and wild elephants in Nepal and to develop responses to threats to long term conservation. Here again, Yonzon applied a combination of field survey and satellite information. Two teams of technical staff were deputed to cover 20 districts in order to collect data on the elephants and forest conditions. The field information was enhanced with GPS, satellite imagery, and GIS and included spatial and temporal information on behavioral ecology, habitat dispersion and attributes of human conflict. In 2008, the Government of Nepal approved a ten-year Elephant Conservation Action Plan based on the report resulting from that study.

Besides the above-mentioned research projects, Yonzon successfully carried out several other studies in Nepal and Bhutan. Whether it was to study a species over a limited range or an ecosystem at the larger landscape level, his worked was always distinguished by innovative methodologies and novel ideas. Because he kept up-to-date on new research and technology, he did not run out of ideas nor did he repeat old successes. For many years to come, we will miss his leadership.

\section{Dinesh Raj Bhuju is "Pragya" (Academician) at National} Academy of Science and Technology, Kathmandu, Nepal.

\section{References}

Caughley G. 1969. Wildlife and Recreation in the Trisuli Watershed and other areas in Nepal. HMG/ FAO/UNDP Trisuli Watershed Development Project. Project Report No 6, Kathmandu

Dinerstein E and L Price. 1991. Demographic characteristics of Greater One-horned Rhinoceros in Nepal. Journal of Wildlife Management 55:401-422

Laurie WA.1978. The Ecology and Behaviour of the Greater OneHorned Rhinoceros. A dissertation submitted to the University of Cambridge for the degree of Doctor of Philosophy

Martin EB and Lucy Vigne. 1996. Nepal's rhinos- one of the greatest conservation success stories. Pachyderm No. 21 1996, pp 10-26

Pelinck E and BN Upreti. 1972. A census of rhinoceros in Chitwan National Park and Tamaspur Forest, Nepal. HMG/FAO/UNDP, National Parks and Wildlife Conservation Project, Kathmandu. Unpublished report

Spillett JJ and KM Tamang. 1966. Wildlife Conservation in Nepal. Journal of Bombay Natural History Society 63: 557-571

Yonzon P. 1994. Count Rhino 1994. Report Series No. 10, WWF Nepal Program, Kathmandu 


\title{
The Himalayan wanderer: Conservationist, scholar and friend
}

\author{
Joel T Heinen
}

I first met Pralad Yonzon in 1985, when he was a lecturer in Zoology and I was a Peace Corps Volunteer and lecturer at the Institute of Forestry. We quickly became friends, and I found his humor and candor refreshing in a culture where much remains hidden. We remained friends to the end, and for this I am grateful.

In 1987 I was living in Koshi Tappu, studying wild buffalo and park-people interactions, and Pralad showed up with a group of 20 American study abroad students for a week-long visit. He and I, along with Warden Ganga Ram Singh, came up with field projects for each group of 3-4 students, and it was during that trip that Pralad and I had the opportunity to discuss things at length. I told him I was keeping migratory and nesting bird records for the area, and would continue to do so until I departed in Spring 1988; he asked me to write up my results for publication in the Journal of the Natural History Museum, for which he was editor. Ultimately we produced two papers, which dedicated birders still cite on occasion. I also told Pralad, in the course of that same visit, that I had begun three review papers about conservation programs in Nepal, and Pralad later co-authored one of those with me (Heinen and Yonzon, 1994, Mountain Research and Development). Again, we had the opportunity to discuss the human aspects of conservation, the types of socio-economic surveys I was doing around Koshi Tappu, and the importance of incorporating that into biodiversity programs. Those discussions helped hone my own research for years to come, and also, I think, helped frame Pralad's red panda work in Langtang, and his many subsequent projects.

It was Pralad whom I first contacted in 1990 when planning a trip to Nepal to study the extent of the fur trade. The result was a paper by Blair Leisure and myself, and a 1994 workshop that Pralad organized. Blair and I were back in Kathmandu then, and Pralad managed to convene high ranking officers from Customs, Police, Wildlife, Forestry, Tourism, and representatives from all the international and several national conservation NGOs; this led to another paper (Heinen, Yonzon and Leisure, 1995, Conservation Biology) and, thankfully, to a great reduction in fur sales to tourists. Pralad sure knew whom to contact, and how to get their attention!

The last time we collaborated directly was during the 1996-1998 Nepal Biodiversity Strategy and Action Plan project, which Pralad chaired. I am ashamed to admit that I let him down then. I had gotten sick for part of my onemonth stay during a hard monsoon, and I was very slow in writing my sections after I returned home. But there were many aspects of the project that Pralad had confided did not go well, including meddling by some HMG officers, jealousies, and bureaucratic inefficiencies. Years later we discussed writing a paper about the pitfalls of that project, but, in retrospect, it is best that paper didn't come about.

With his founding of Resources Nepal, and its expansion to Resources Himalaya and the Resources Himalaya
Foundation over the course of two decades, Pralad never ceased to amaze me. Each trip to Kathmandu allowed many long discussions in which he would tell me in detail about his myriad projects. I still have my "Count Rhino 1994" tee shirt, a gift from Pralad. But initiating a Biodiversity Strategy and Action Plan for Vietnam, a place he knew little about, and successfully carrying it off? Not likely! Yet that is just what Pralad did. His forays to Bhutan particularly intrigued me, as I could imagine that a century ago much of Nepal would have been like that. But tigers at tree line? Not likely! Yet that is what he showed with a famous picture he took ten years ago. Still, I believe Pralad most enjoyed his work in Nepal. He told me many details about his time in Manang and Mustang while preparing the Annapurna management plan, and his forays into Kanchanjunga when it was considered for Conservation Area status. It was pure luck that Pralad was not killed there in the helicopter crash of September 2006, which took the lives of many great colleagues; he had been invited to go, but declined.

In 2007 we received the wonderful news that Pralad Yonzon and Resources Himalaya Foundation were awarded a MacArthur. Pralad remained a true mentor, teacher and friend until the end. He encouraged a number of Nepali students over the years to apply for graduate studies with me; the most recent, Mr. Yogesh Dongol, had worked for both Resources Himalaya and also Wildlife Conservation Nepal, the NGO founded and managed by Pralad's younger brother Prasanna Yonzon before embarking on his Masters program. Yogesh completed a study on illegal wildlife trade in Nepal in 2010, and the Yonzons helped him in every way.

When I heard of Pralad's death, I could not help but reflect on the irony of a person so vigorous and positive, who had lived at high elevation under rigorous conditions, who had encountered tigers, rhinos, cobras, and any number of lethal characters, had finally succumbed to such a pedestrian agent. But perhaps Pralad would have preferred it this way, while still at the top of his game, and before the ravages of old age took hold. I don't know. I am also unsure how to sum up the life of such an accomplished person and good friend. Upon hearing of Pralad's death, I wrote a song that goes, in part:

Who knows when the Mountain Gods will come to call you home,

To be with the griffon and the lammergeier

I know that he'll be watching them, and I know he's not alone,

But I'll miss the Himalayan Wanderer

I'll sing it for you sometime. And, yes, I'll miss the Himalayan Wanderer.

Heinen is a professor at Department of Earth and Environment, Florida International University, Miami, FL, USA. 